\title{
Regional Frequencies of Virulence in Oat Crown Rust in the United States from 1990 Through 2000
}

\author{
K. J. Leonard, formerly U.S. Department of Agriculture, Agricultural Research Service, Cereal Disease Labora- \\ tory, University of Minnesota, St. Paul 55108
}

\begin{abstract}
Leonard, K. J. 2003. Regional frequencies of virulence in oat crown rust in the United States from 1990 through 2000. Plant Dis. 87:1301-1310.

More than 2,000 isolates of Puccinia coronata f. sp. avenae collected in national virulence surveys were analyzed to determine regional patterns of virulence on 28 single-gene oat lines. From 1990 to 2000, frequencies of virulence to eight differentials increased significantly in Texas, and virulence frequencies of four of the eight also increased in the northern Great Plains. No significant changes occurred for the other 20 differentials. Isolates from northern states from the Dakotas to New York had similar patterns of virulence frequencies on these 20 differentials. The pattern of virulence frequencies in the north differed from that of southern states from Texas to the Carolinas. There was a gradient of similarity values in state by state comparisons from Texas to the Atlantic Coast. Isolates from California were distinctly different from those elsewhere in the United States. Isolates from the South and from California had greater mean virulence complexity than isolates from northern states. Collections from the central Great Plains were intermediate between northern and southern isolates. Uredinial isolates from oat and aecial isolates from the alternate host Rhamnus cathartica in Minnesota had similar frequencies of virulence, as did isolates from cultivated oat and wild Avena fatua in North Dakota. Maintenance of large numbers of stable virulence polymorphisms with different regional allele frequencies is consistent with the operation of some form of stabilizing selection.
\end{abstract}

Additional keywords: genetic diversity, population structure

Crown rust, caused by Puccinia coronata f. sp. avenae, is one of the most serious diseases of oat in the United States and Canada. Estimated yield losses from crown rust for the 10-year period 1991 to 2000 averaged $5.8 \%$ for Minnesota, $4.4 \%$ for South Dakota, and $4.4 \%$ for Louisiana (13). Estimated losses in individual years were as high as $15 \%$ in South Dakota in 1991 and 1993, 20\% in Minnesota in 1991, and 20 and 10\% in 1997 and 1995 in Louisiana (13). Years with greatest losses to crown rust correspond to years of favorable weather (i.e., moderate to high summer temperatures with high humidity leading to abundant dew at night [23]) and emergence of new virulence to overcome the race-specific resistance in common oat cultivars (25).

Oat crown rust race surveys have been conducted in the United States since 1927

Corresponding author: K. J. Leonard

E-mail: kurtl@umn.edu

Current address of K. J. Leonard: Department of Plant Pathology, University of Minnesota, St. Paul, MN 55108.

Accepted for publication 28 May 2003.

Publication no. D-2003-0911-02R

This article is in the public domain and not copyrightable. It may be freely reprinted with customary crediting of the source. The American Phytopathological Society, 2003.
(17). The two principal objectives of the race surveys were to furnish data on the year-to-year prevalence of known races and to detect new and potentially dangerous races as soon as possible after their appearance (24). Insofar as differential sets for pathogenic race identification remain constant over a period of time, the race surveys can also be a source of information about population structure and epidemiological zones for cereal rust diseases $(1,2,9-$ 11). Care must be taken, however, in using virulence frequencies to compare rust populations across space or time, because virulence genes may be subject to strong selection pressures when corresponding resistance genes are used in common host cultivars. To characterize long-term underlying differences between rust populations, it is important to compare neutral markers rather than markers that may have diverged very recently due to strong selection in one state or region but not another. Neutral markers are essential when comparisons involve combining data collected over several years to characterize regional diversity.

National virulence surveys for oat crown rust have been conducted at the Cereal Disease Laboratory in St. Paul, MN, since 1990. During that time, a core group of 28 crown rust differential lines has been used. Large numbers of collections of $P$. coronata $\mathrm{f}$. sp. avenae have been obtained and analyzed in nearly every year from several states including Minnesota, North Dakota, South Dakota, and Texas. For many other states, however, the numbers of isolates for any given year were often quite small. Thus, it has not been possible to obtain a clear understanding of how the virulence frequencies of $P$. coronata $\mathrm{f}$. sp. avenae vary from state to state across the United States based on survey data from any single year.

The objectives of this study were (i) to compare frequencies of virulence in the northern Great Plains region (Minnesota, North Dakota, and South Dakota) and the southern Great Plains (Texas) on 28 crown rust differential lines of oat over the 11year period from 1990 through 2000, (ii) to identify virulences that did not change significantly in frequency in either region during this period, and (iii) to use pooled frequency data over years for those stable virulences in state-by-state comparisons to identify broad regions of shared virulence frequencies in $P$. coronata $\mathrm{f}$. sp. avenae populations across the United States.

\section{MATERIALS AND METHODS}

Samples, each consisting of several crown rust infected leaves, were collected from oat fields and breeders' nurseries encountered in annual surveys of wheat rusts along routes totaling approximately $22,000 \mathrm{~km}$ in the Great Plains, Ohio Valley, and Southeast from 1990 through 2000 (11). Field surveys were made in southern Texas (early April), northern Texas (late April), the southeastern Gulf Coast states (mid-April to early May), Oklahoma and Kansas (mid-May), Wisconsin, Illinois, and the Ohio River Valley (early June), Nebraska, South Dakota, and southern Minnesota (mid-June), and North Dakota and northern Minnesota (early July and late July). Collections were made in oat fields along the route and in breeders' nurseries in each state surveyed. Collections were also made from wild Avena fatua plants found in wheat fields and roadsides, particularly in the northern Great Plains. In addition, numerous collections of oat crown rust were contributed by collaborators throughout the United States, notably L. Jackson and J. Shafer (California), M. McDaniel and R. Harrington (Texas), S. Harrison (Louisiana), K. B. Burch (Alabama), J. R. Roberts (southeastern states), W. Graham (South Carolina), Y. Jin, D. Gustafson, and D. Reeves (South Dakota), J. Miller (North Dakota), H. J. 
Kaeppler (Wisconsin), G. Bergstrom (New York), G. Schumann (Massachusetts), and E. Flack (Pennsylvania). In addition to collections of uredinia from oat, $7 \%$ of the $P$. coronata $\mathrm{f}$. sp. avenae isolates evaluated in this study were obtained from aecial collections from the alternate host, Rhamnus cathartica (Table 1). Aecial collections were provided by A. P. Roelfs (midwestern states), R. Laudon (Minnesota), Y. Jin (Minnesota, North Dakota, South Dakota), G. F. Lehrer (Wisconsin), and G. Bergstrom (New York). Collections from the buckthorn nursery at St. Paul, MN, were excluded from these analyses to avoid a high concentration of collections from a single location.

Urediniospores were collected from each sample of oat leaves with a cyclone spore collector and used to inoculate 7- to which is susceptible to all known races of $P$. coronata $\mathrm{f}$. sp. avenae. The seedlings were sprayed with a suspension of urediniospores in lightweight mineral oil, left for $30 \mathrm{~min}$ to allow the oil to evaporate, and then placed overnight in a dew chamber at $18^{\circ} \mathrm{C}$. Similar procedures were used in collecting aeciospores for inoculation from infected leaves of $R$. cathartica. The inoculated seedlings were then returned to the greenhouse $\left(18\right.$ to $\left.28^{\circ} \mathrm{C}\right)$. When uredinia appeared, the seedlings inoculated with each urediniospore or aeciospore collection were trimmed to a single uredinium. The seedlings were then placed in a dew chamber for 2 to $3 \mathrm{~h}$ to promote germination of 9-day-old seedlings of cv. Marvellous oat,

urediniospores scattered on the leaf surface and then dried to kill the germinating spores. Trimmed plants bearing single uredinia were then placed in polyethylene isolation cells in the greenhouse for several days to allow further sporulation in the single uredinia. Urediniospores were collected from the single-uredinial isolates and increased through one more uredinial generation on 'Marvellous' oat seedlings in isolation cells. Single-uredinial isolates were stored dry at $-50^{\circ} \mathrm{C}$ if not used within 2 weeks of collection. Shorter term storage was at $20 \%$ relative humidity $(\mathrm{RH})$ at $4{ }^{\circ} \mathrm{C}$.

Each isolate was tested for virulence on a susceptible control (cv. Starter) and a set of 28 backcross lines of oat each with a different single $P c$ gene for seedling crown rust resistance (Table 2). Except for $P c-14$ from cv. Ascencao, all of the crown rust resistance genes in the differential set were derived from collections of wild oat, $A$. sterilis, from the Mediterranean region $(3,5,7,20,26,28)$. The differential lines were grown in vermiculite in $7-\mathrm{cm}$ square plastic pots with seeds of four lines planted in the four corners of each pot. There were 10 to 20 seedlings per line. At 7 to 10 days after planting, the primary leaves of seedlings in each set of 28 differential lines were inoculated with freshly collected urediniospores of a single-uredinial isolate suspended in lightweight mineral oil as described above. Inoculated plants were kept in a dew chamber overnight and then placed on a greenhouse bench. Disease reactions were evaluated 12 to 15 days

Table 1. Source of isolates of Puccinia coronata f. sp. avenae from 1990 to 2000

\begin{tabular}{lccc}
\hline State & $\begin{array}{c}\text { Average oat area } \\
\mathbf{1 9 9 0 - 2 0 0 0}(\mathbf{1 , 0 0 0} \text { ha })\end{array}$ & $\begin{array}{c}\text { Number of } \\
\text { uredinial isolates }\end{array}$ & $\begin{array}{c}\text { Number of } \\
\text { aecial isolates }\end{array}$ \\
\hline Alabama & 10 & 87 & 0 \\
Arkansas & 9 & 6 & 0 \\
Arizona & NA $^{\mathrm{b}}$ & 1 & 0 \\
California & 12 & 42 & 0 \\
Florida & $\mathrm{NA}$ & 46 & 0 \\
Georgia & 16 & 32 & 0 \\
Illinois & 35 & 8 & 12 \\
Iowa & 114 & 10 & 19 \\
Kansas & 33 & 10 & 0 \\
Louisiana & $\mathrm{NA}$ & 222 & 0 \\
Massachusetts & $\mathrm{NA}$ & 11 & 0 \\
Minnesota & 162 & 18 & 73 \\
Mississippi & $\mathrm{NA}$ & 6 & 0 \\
Montana & $\mathrm{NA}$ & 5 & 0 \\
Nebraska & 53 & 31 & 0 \\
New York & 39 & 12 & 6 \\
North Carolina & 13 & 211 & 0 \\
North Dakota & 184 & 7 & 10 \\
Ohio & 51 & 5 & 0 \\
Oklahoma & 12 & 13 & 0 \\
Pennsylvania & 69 & 26 & 0 \\
South Carolina & 13 & 129 & 0 \\
South Dakota & 175 & 5 & 5 \\
Tennessee & $\mathrm{NA}$ & 633 & 0 \\
Texas & 55 & 1 & 0 \\
Virginia & $\mathrm{NA}$ & 65 & 0 \\
Wisconsin & 164 & 1967 & 9 \\
Total & & & 134 \\
- & & 18 &
\end{tabular}

a Data from National Agricultural Statistics Service.

${ }^{\mathrm{b}}$ No data available. after inoculation. Responses with moderately large to large pustules with little or no chlorosis were scored as susceptible reactions, those with flecks or small pustules surrounded by chlorosis or necrosis were scored as resistant.

For analysis of year-to-year variation in frequencies of isolates virulent on each differential line, the isolates from Minnesota, North Dakota, and South Dakota were pooled and compared with isolates from Texas. The numbers of isolates from each year for these two regions are shown in Table 3. For each of the two regions, a linear regression was calculated for virulence frequencies on each differential line over the years 1990 through 2000, with years being the independent variable and virulence frequency the dependent variable. Differential lines for which the slope of the linear regression of virulence frequency over years did not differ significantly $(P<0.05)$ from 0.0 were regarded as representing resistance genes that did not show a significant effect of selection or gene flow on the populations during the years of the survey.

Data from the 20 differential lines for which the virulence frequency did not change significantly in either Texas or the northern Great Plains states during 1990 to 2000 were used to compare phenotype similarity among collections of isolates from different states. For these comparisons, the data from 1990 to 2000 were pooled over years by state. For state-bystate comparisons, a sample size of at least 30 isolates per state was deemed necessary for reliable determination of genetic distances (15). Data from Mississippi, Montana, Ohio, and Tennessee were dropped from the analysis because of the small numbers of isolates from those states. In other cases, data from adjacent states were pooled to obtain an adequate sample size. Thus, the single isolate from Arizona was included with the California data, and the data from South Carolina, North Carolina, and Virginia were combined, as were the data from New York, Pennsylvania, and Massachusetts and the data from Iowa and Illinois (Fig. 1). Even though there were few isolates from Nebraska, Kansas, Oklahoma, and Arkansas, the isolates from this region were pooled to test the hypothesis that these states may represent an area of mixing between the populations of $P$. coronata f. sp. avenae from Texas and the northern Great Plains states.

Genetic distances between populations of isolates in all possible pairs of states (or pooled groups of states) were determined by calculating a similarity index (SI) for each pair based on absolute differences in virulence frequencies

$$
\mathrm{SI}=\frac{1}{N} \sum_{i=1}^{N}\left|p_{i A}-p_{i B}\right|
$$

in which $N$ is the number of host lines in the differential set, $p_{i A}$ is the percent fre- 
quency of virulence on the $i$ th differential line in population $A$, and $p_{i B}$ is the percent frequency of virulence on the $i$ th differential line in population B (14). Thus, states with identical frequencies of virulence over all differential lines would have a value of $\mathrm{SI}=0.0$. Greater values of SI indicate greater genetic distances between states.

Table 2. Regression of virulence frequency on oat crown rust differentials over years for collections of Puccinia coronata f. sp. avenae from Texas versus northern Great Plains states of Minnesota, North Dakota, and South Dakota for the years 1990 to 2000

\begin{tabular}{|c|c|c|c|c|}
\hline \multirow[b]{2}{*}{ Line } & \multicolumn{2}{|c|}{ TX } & \multicolumn{2}{|c|}{ MN, ND, SD } \\
\hline & $\operatorname{Mean}^{a}(\%)$ & Slope ${ }^{b}$ & Mean $(\%)$ & Slope \\
\hline Pc-14 & 86 & 1.88 & 86 & -1.07 \\
\hline$P c-35$ & 58 & 1.85 & 42 & -0.38 \\
\hline$P c-36$ & 45 & $4.32 * *$ & 51 & $3.51 *$ \\
\hline$P c-38$ & 31 & $3.97 * *$ & 60 & 1.09 \\
\hline$P c-39$ & 28 & $4.89 * *$ & 54 & 2.14 \\
\hline$P c-40$ & 88 & 1.04 & 69 & 0.02 \\
\hline Pc-45 & 14 & -1.35 & 3 & 0.06 \\
\hline$P c-46$ & 32 & 3.33 & 34 & 0.74 \\
\hline Pc-48 & 8 & -0.14 & 7 & 0.03 \\
\hline$P c-50$ & 26 & 0.81 & 10 & -0.10 \\
\hline$P c-51$ & 71 & 2.23 & 51 & 0.55 \\
\hline$P c-52$ & 5 & 0.59 & 6 & 0.90 \\
\hline$P c-53$ & 6 & 0.96 & 2 & -0.29 \\
\hline$P c-54$ & 25 & -1.94 & 13 & -1.18 \\
\hline$P c-56$ & 46 & $3.14 *$ & 51 & 3.63 \\
\hline$P c-57$ & 34 & $5.26^{*}$ & 23 & $3.66^{*}$ \\
\hline Pc-58 & 19 & -0.31 & 6 & -0.58 \\
\hline$P c-59$ & 43 & 1.51 & 29 & 1.17 \\
\hline$P c-60$ & 77 & 1.71 & 51 & 0.21 \\
\hline$P c-61$ & 70 & 1.77 & 36 & 2.32 \\
\hline$P c-62$ & 1 & 0.08 & 5 & 0.20 \\
\hline$P c-63$ & 24 & $2.95^{*}$ & 49 & 0.27 \\
\hline$P c-64$ & 8 & 1.19 & 9 & -0.27 \\
\hline$P c-67$ & 53 & -2.13 & 41 & -0.82 \\
\hline Pc-68 & 2 & -0.05 & 1 & 0.07 \\
\hline$P c-70$ & 32 & $4.93 * *$ & 41 & $3.03 *$ \\
\hline$P c-71$ & 28 & $5.25 * *$ & 53 & $2.38 *$ \\
\hline $\mathrm{H} 548^{\mathrm{c}}$ & 5 & -0.03 & 5 & 0.16 \\
\hline
\end{tabular}

${ }^{a}$ Mean percentage of isolates virulent on each differential line calculated as sum of means for individual years/total number of years.

b * indicates slope significantly different from 0.0 at $P<0.05$; ** indicates slope significantly different from 0.0 at $P<0.01$

${ }^{\mathrm{c}}$ Line H548 contains an unidentified gene for crown rust resistance transferred from Avena sterilis accession PI 296251.

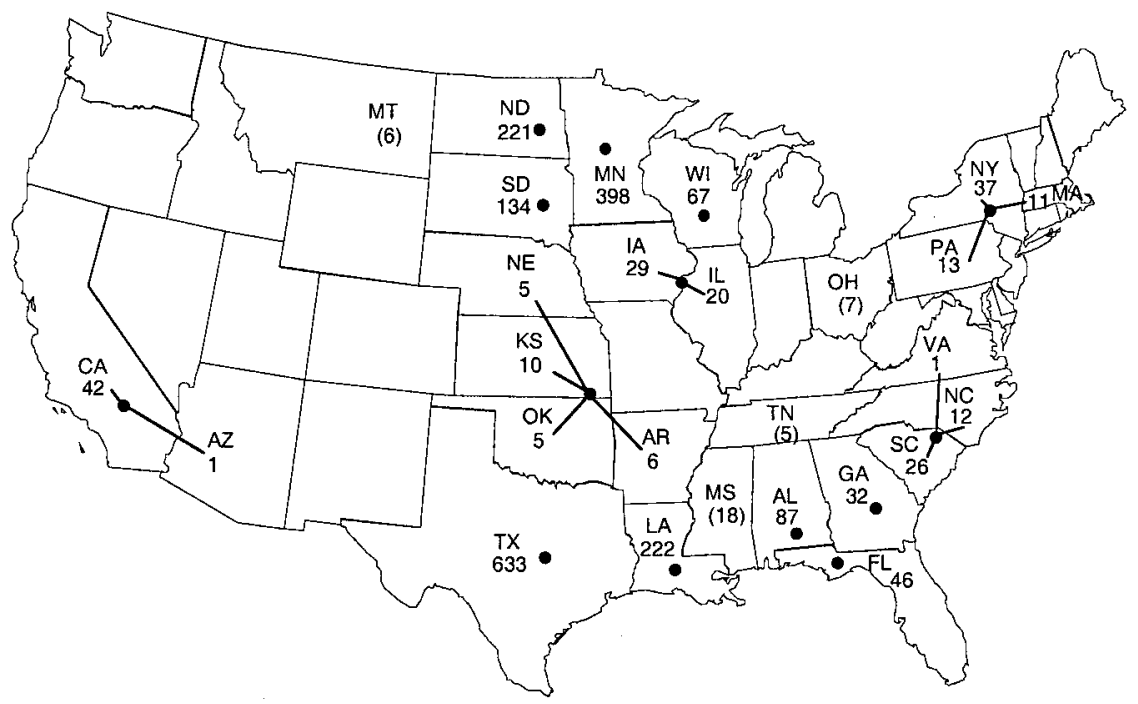

Fig. 1. Geographical distribution of collections of isolates of Puccinia coronata f. sp. avenae from 1990 to 2000. Each dot represents a population of isolates used in comparisons of phenotypic distance. Data were pooled for Arkansas, Oklahoma, Kansas, Nebraska; for Illinois, Iowa: for South Carolina, North Carolina, Virginia: and for New York, Pennsylvania, Massachusetts. Numbers indicate the number of isolates collected from each state. Numbers in parentheses indicate isolates that were not included in the analyses. A minimum of 30 isolates per state or pooled region was desirable for reliable comparisons.

Regional collections of $P$. coronata f. sp. avenae isolates were also compared for individual virulence frequencies and mean virulence complexity, which was calculated as the mean number of virulences per isolate detected on differential lines that showed no significant changes of virulence over the years 1990 to 2000. Regional means of virulence complexity were calculated for the South (Texas to Virginia), North (North and South Dakota to Massachusetts), and central states (Arkansas, Oklahoma, Kansas, Nebraska, Iowa, and Illinois) as the average of state means within each region. The western region was represented by California. Differences in virulence frequencies between the North and South, South and central states, North and central states, and North and California were compared statistically by pooling data over all states within each region and computing the interaction $\chi^{2}$ value to test for homogeneity in $2 \times 2$ contingency tables. A correction for continuity was used to calculate the adjusted $\chi^{2}$ value (27). Because the $\chi^{2}$ test was used for many comparisons, which is likely to lead to increased Type I errors, a conservative significance level of $P<0.01$ was used to test for differences between regions.

A similarity index was calculated for uredinial isolates and aecial isolates from Minnesota to determine whether combining uredinial and aecial isolates would introduce any systematic error in comparisons between states. Minnesota was the only state with more than 30 aecial collections. Likewise, isolates from cultivated oat, Avena sativa, in North Dakota were compared with isolates from wild oat, A. fatua. North Dakota was the only state with more than 30 isolates collected from A. fatua. The adjusted $\chi^{2}$ test was used to compare virulence frequencies between uredinial and aecial isolates from Minnesota in 1994 and 1995 and between uredinial isolates from $A$. fatua and A. sativa in North Dakota over all years as described for comparisons of virulence frequencies between regions.

Table 3. Numbers of isolates of Puccinia coronata f. sp. avenae obtained from Texas and from the northern Great Plains states of Minnesota, North Dakota, and South Dakota from 1900 though 2000

\begin{tabular}{ccc}
\hline Year & Texas & $\begin{array}{c}\text { Northern Great } \\
\text { Plains states }^{\mathbf{a}}\end{array}$ \\
\hline 1990 & 19 & 33 \\
1991 & 105 & 43 \\
1992 & 101 & 33 \\
1993 & 23 & 120 \\
1994 & 47 & 134 \\
1995 & 110 & 104 \\
1996 & 18 & 57 \\
1997 & 37 & 43 \\
1998 & 36 & 31 \\
1999 & 95 & 74 \\
2000 & 42 & 77 \\
\hline
\end{tabular}

a Pooled data from Minnesota, North Dakota, and South Dakota. 


\section{RESULTS}

Variation in virulence frequencies. In the period 1990 to 2000 , there were highly significant $(P<0.01)$ increases in the frequencies of virulence in Texas to differential lines with resistance genes $P c-36, P c$ 38, $P C-39, P c-70$, and $P c-71$, and significant $(P<0.05)$ increases in the frequencies of virulence on $P c-56, P c-57$, and $P c-63$ (Table 2). In Minnesota, North Dakota, and South Dakota, there were significant $(P<$ $0.05)$ increases in virulence to $P c-36, P c$ 57, $P c-70$, and $P c-71$. Representative regression lines are shown for $P c-36, P c-38$, and $P c$-71 (Fig. 2).

Aecial versus uredinial isolates. Aecial isolates collected from the buckthorn nursery at St. Paul, MN, were excluded from the comparison of virulence frequencies among aecial and uredinial isolates collected from Minnesota. Among the field isolates, 72 of the total 73 aecial isolates were collected in 1994 and 1995 . These 72 aecial isolates were compared with the 87 uredinial isolates collected in Minnesota in 1994 and 1995 as well as with the total 323 uredinial isolates collected in Minnesota from 1990 to 2000 (Table 4). The frequency of virulence on the $P c-45$ differential line was significantly greater $(P<$ 0.01 ) among aecial isolates than among uredinial isolates collected from 1994 to 1995 or uredinial isolates collected over all years. In all other comparisons between aecial isolates and 1994 to 1995 uredinial isolates, differences in virulence frequency were not significant even at $P<0.1$. The same is true for comparisons between aecial isolates and uredinial isolates collected over all years except that the frequency of virulence on the $P c-60$ line was greater $(P<0.05)$ among uredinial isolates collected over all years than among aecial isolates. No other differences were significant even at $P<0.1$.

Over these 20 differential lines, the average similarity index between aecial and uredinial isolates was 5.01 for isolates from 1994 to 1995 or 4.58 for uredinial isolates from all years (Table 4). The average number of virulence factors (virulence complexity) detected with the set of 20 differential lines for aecial isolates was 5.9. The average for uredinial isolates from

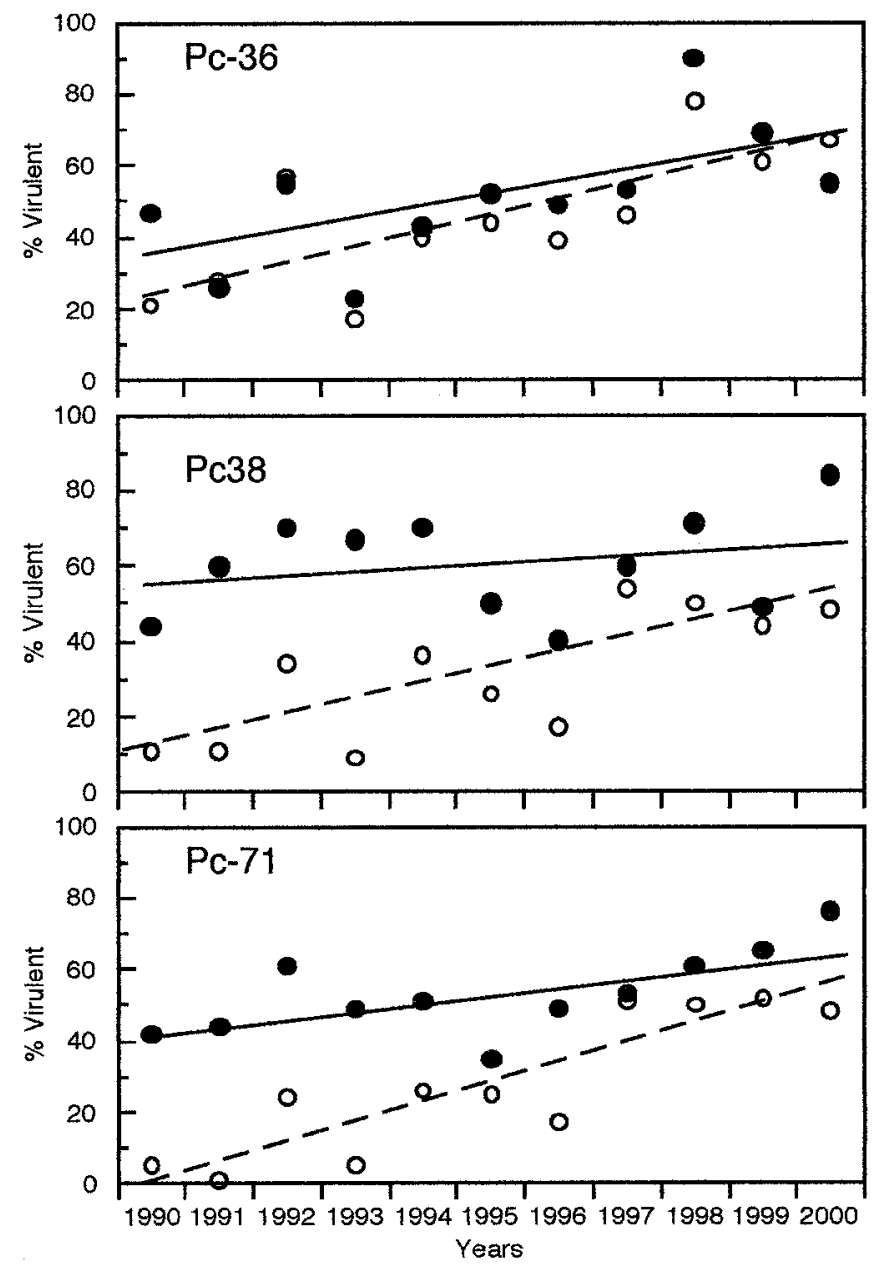

Fig. 2. Regression of frequency of virulence on the $P c-36, P c-38$, and $P c-71$ differential oat lines over the years 1990 to 2000 for collections of isolates of Puccinia coronata f. sp. avenae from Texas (open circles, dashed lines) and from the northern Great Plains states of Minnesota, North Dakota, and South Dakota (closed circles, solid lines). The slope of the regression for virulence on $P c-38$ in collections from Minnesota, North Dakota, and South Dakota is not significantly different from 0.0 $(P>0.05)$. Slopes of all other regression lines are significantly greater than $0.0(P<0.05)$.
1994 to 1995 was 5.8 , and the average for 1990 to 2000 was 5.2. The average complexity did not differ significantly for aecial and uredinial isolates from 1994 to 1995 ( $t$ test, $P=0.710$ ).

Uredinial isolates from cultivated versus wild oat. Isolates of $P$. coronata $\mathrm{f}$. $\mathrm{sp}$. avenae were obtained from wild $A$. fatua in six states. The greatest number $(n=63)$ made up $30 \%$ of the uredinial isolates from North Dakota. California had 17 isolates (40\%), Minnesota 23 isolates (7\%), South Dakota 8 isolates $(6 \%)$, and Texas 15 isolates $(2 \%)$ from $A$. fatua. There was also one isolate from $A$. fatua in Nebraska. Uredinial isolates from $A$. sativa and $A$. fatua from North Dakota were compared to determine whether the uredinial host species affected virulence frequencies, because North Dakota was the only state with $>30$ isolates from A. fatua. There were no significant differences $(P<0.05)$ in virulence frequencies between isolates from $A$. fatua and A. sativa on any of the differentials (Table 5). The similarity index for isolates from the two uredinial hosts, 3.19, also indicates a high degree of similarity between isolates from the two hosts. The mean virulence complexity for the isolates from A. fatua, 4.76, was only slightly less than the mean virulence complexity of 4.94 for isolates from A. sativa in North Dakota.

Phenotypic distances between states and regions. The matrix of similarity index values was arranged to separate northern and southern states (Table 6). Collections of $P$. coronata f. sp. avenae from northern states of North Dakota, South Dakota, Minnesota, Wisconsin, and the pooled isolates from New York, Pennsylvania, and Massachusetts clustered together. Within this cluster, the similarity index values range from 3.54 to 6.26 . The similarity index of 4.58 for uredinial isolates versus aecial isolates from Minnesota fits within this range, and the similarity index of 3.19 for isolates from A. fatua and A. sativa from North Dakota is even lower. Collections of isolates from southern states were generally more similar to each other than to collections from any of the northern states. However, isolates from Georgia and from the pooled collection from South Carolina, North Carolina, and Virginia appeared somewhat distinct from collections of isolates from the other southern states. Collections of isolates from areas between the North and South, i.e., Arkansas, Oklahoma, Kansas, Nebraska, and Illinois, Iowa, were more similar to collections from Texas and Louisiana than to collections from other states. Isolates of $P$. coronata f. sp. avenae from California were distinctly different from those of the rest of the United States in their virulence frequencies (Table 6).

To visualize the relationships among collections of $P$. coronata f. sp. avenae isolates in another way, the dissimilarity of each collection of isolates from the Texas 
isolates was plotted versus the dissimilarity from North Dakota isolates (Fig. 3). Selecting reference states at the western edge of the northern and southern regions reveals whether increasing geographical distance from east to west is associated with any measurable change in genetic distance among northern or southern collections. Collections from Minnesota, South Dakota, Wisconsin, and the pooled New York, Pennsylvania, Massachusetts collection clustered together with high similarity to North Dakota and less similarity to Texas. Collections from Louisiana, Alabama, Florida, and the pooled Illinois, Iowa and Arkansas, Oklahoma, Kansas, Nebraska collections clustered with high similarity to Texas and relatively low similarity to North Dakota. The data points for Georgia and for the pooled South Carolina, North Carolina, Virginia collections were outliers with relatively low similarity to either Texas or North Dakota.

When the dissimilarity indexes were plotted against North Dakota on one axis and the pooled New York, Pennsylvania, Massachusetts collection on the other axis, similarity to the North Dakota collection of isolates was highly correlated with similarity to the pooled collection from New York, Pennsylvania, Massachusetts (Fig. 4). Collections of isolates from Arkansas, Oklahoma, Kansas, Nebraska; from Illinois, Iowa; and from South Carolina, North Carolina, Virginia showed intermediate levels of similarity to those of the northern states compared with southern states.

The gradient of relationships among collections of $P$. coronata $\mathrm{f}$. sp. avenae from southern states can be seen in the plot of dissimilarity indexes against the collections from Texas on one axis and the pooled collection from South Carolina, North Carolina, Virginia on the other (Fig. 5). Two regression lines can be drawn in this plot: one from the points for Louisiana through Georgia representing the Gulf Coast and central states, and one from North Dakota through Wisconsin representing the northern states. The first regression line indicates that populations of $P$. coronata f. sp. avenae in southern states diverge from the Texas population as they approach the South Carolina, North Carolina, Virginia population. Thus, the Louisiana population is most like the Texas population and least like the South Carolina, North Carolina, Virginia population, whereas the Georgia population is least like the Texas population and most like the South Carolina, North Carolina, Virginia population. For the northern populations, however, similarity to the South Carolina, North Carolina, Virginia population decreases as similarity to the Texas population decreases.

Another measure of the geographic scale of virulence similarities can be obtained by identifying the most similar pairs of state collections. In the South, the similarity index for each state except one is most similar to that of a contiguous state (Table 6). For example, the collection of isolates

from Texas is most similar to the collection from Louisiana, and the pooled collection from South Carolina, North Carolina, Virginia is most similar to the collection from

Table 4. Virulence frequencies (\%) on 20 crown rust differential lines ${ }^{\mathrm{a}}$ for aecial ${ }^{\mathrm{b}}$ and uredinial collections ${ }^{\mathrm{c}}$ of Puccinia coronata f. sp. avenae from Minnesota

\begin{tabular}{|c|c|c|c|c|c|}
\hline \multirow[b]{2}{*}{ Line } & \multirow[b]{2}{*}{ Aecia } & \multicolumn{2}{|c|}{ All years } & \multicolumn{2}{|c|}{ 1994-1995 } \\
\hline & & Uredinia & $\mid$ diff.|d & Uredinia & |diff.| \\
\hline$P c-14$ & 86 & 90 & 4.23 & 91 & 4.48 \\
\hline$P c-35$ & 46 & 40 & 6.27 & 38 & 8.19 \\
\hline$P c-40$ & 75 & 70 & 4.65 & 84 & 8.72 \\
\hline$P c-45$ & 14 & 2 & $11.71^{* *}$ & 1 & $12.73 * *$ \\
\hline$P c-46$ & 44 & 39 & 5.94 & 39 & 5.36 \\
\hline$P c-48$ & 6 & 6 & 0.02 & 1 & 4.41 \\
\hline$P c-50$ & 15 & 12 & 3.67 & 11 & 4.69 \\
\hline$P c-51$ & 48 & 53 & 5.61 & 56 & 8.50 \\
\hline$P c-52$ & 6 & 4 & 1.22 & 2 & 3.26 \\
\hline$P c-53$ & 1 & 1 & 0.44 & 1 & 0.24 \\
\hline$P c-54$ & 21 & 16 & 4.73 & 13 & 8.19 \\
\hline Pc-58 & 7 & 8 & 0.67 & 12 & 5.05 \\
\hline$P c-59$ & 27 & 26 & 1.57 & 24 & 3.33 \\
\hline$P c-60$ & 73 & 57 & $16.05^{*}$ & 74 & 1.18 \\
\hline$P c-61$ & 48 & 42 & 6.25 & 52 & 4.44 \\
\hline$P c-62$ & 6 & 3 & 2.38 & 5 & 0.96 \\
\hline$P c-64$ & 6 & 9 & 3.45 & 9 & 3.64 \\
\hline$P c-67$ & 50 & 40 & 10.06 & 61 & 10.92 \\
\hline Pc-68 & 3 & 1 & 1.54 & 3 & 0.67 \\
\hline H548 & 6 & 5 & 1.23 & 5 & 1.18 \\
\hline Mean & & & 4.58 & & 5.01 \\
\hline
\end{tabular}

${ }^{a}$ Differential lines for which significant changes in virulence frequencies occurred in either Texas or the northern Great Plains states were excluded from these comparisons.

b Only aecial isolates from 1994 and 1995 are included in the table, because 72 of the total 73 aecial isolates were collected in 1994 and 1995. This allows comparisons of aecial isolates and uredinial isolates from 1994 and 1995 as well as of aecial isolates and uredinial isolates collected over all years from 1990 to 2000 .

c The numbers of uredinial isolates from Minnesota were 87 for 1994 to 1995 and 323 for 1990 to 2000, and the number of aecial isolates from Minnesota was 72 .

d Absolute values of differences are presented to two decimal places, whereas values of virulence frequencies are rounded to the nearest whole percentage. Statistically significant differences (adjusted $\chi^{2}$ test) between uredinial isolates and aecial isolates are indicated by $* *(P<0.01)$ or $*(P<$ $0.05)$; no other differences are significant even at $P<0.1$.

Table 5. Virulence frequencies (\%) on 20 crown rust differential lines ${ }^{\mathrm{a}}$ for uredinial collections $\mathrm{s}^{\mathrm{b}}$ of $P u c$ cinia coronata f. sp. avenae from cultivated (Avena sativa) versus wild (A. fatua) oats in North Dakota

\begin{tabular}{|c|c|c|c|}
\hline \multirow[b]{2}{*}{ Line } & \multicolumn{2}{|c|}{ Virulence of isolates $(\%)$} & \multirow[b]{2}{*}{$\mid$ diff. $\left.\right|^{\mathbf{c}}$} \\
\hline & Avena sativa & Avena fatua & \\
\hline$P c-14$ & 82 & 85 & 3.75 \\
\hline$P c-35$ & 43 & 42 & 1.47 \\
\hline$P c-40$ & 74 & 73 & 0.86 \\
\hline$P c-45$ & 3 & 5 & 2.29 \\
\hline$P c-46$ & 27 & 23 & 3.45 \\
\hline$P c-48$ & 8 & 5 & 3.13 \\
\hline$P c-50$ & 8 & 7 & 1.24 \\
\hline$P c-51$ & 50 & 52 & 1.48 \\
\hline$P c-52$ & 7 & 4 & 3.10 \\
\hline$P c-53$ & 4 & 0 & 3.64 \\
\hline$P c-54$ & 8 & 5 & 3.13 \\
\hline$P c-58$ & 8 & 0 & 7.59 \\
\hline$P c-59$ & 27 & 29 & 1.75 \\
\hline$P c-60$ & 48 & 37 & 10.49 \\
\hline$P c-61$ & 27 & 31 & 3.64 \\
\hline$P c-62$ & 9 & 7 & 1.82 \\
\hline$P c-64$ & 7 & 11 & 3.44 \\
\hline$P c-67$ & 47 & 50 & 2.73 \\
\hline$P c-68$ & 1 & 0 & 1.21 \\
\hline H548 & 5 & 9 & 3.63 \\
\hline Mean & & & 3.19 \\
\hline
\end{tabular}

${ }^{a}$ Differential lines for which significant changes in virulence frequencies occurred in either Texas or the northern Great Plains states were excluded from these comparisons.

${ }^{\mathrm{b}}$ There were 165 isolates from A. sativa and 56 isolates from A. fatua in North Dakota.

${ }^{c}$ Absolute values of differences are presented to two decimal places, whereas values of virulence frequencies are rounded to the nearest whole percentage. 
the neighboring state of Georgia. The exception to this pattern in the South is that the collection of isolates from Alabama is slightly more similar to the collection from Texas than to the collection from Louisiana. In the North, the pattern is more uniform geographically. While it is true that the collections from South Dakota, Minnesota, and Wisconsin all show a close similarity, the collection from North Dakota and the pooled collection from New York, Pennsylvania, Massachusetts at opposite ends of the geographical continuum are more similar to each other than to any of the other collections from the northern states. Oddly, the virulence frequencies in the collection from California are more similar to those of the pooled collections from New York, Pennsylvania, Massachusetts and from South Carolina, North Carolina, Virginia on the Atlantic Coast than to any other state collections in regions geographically nearer to California (Table 6).

In these analyses, the data from Ohio were not considered. To test whether including the Ohio data would affect the analyses, the similarity indexes were recalculated using pooled data from Ohio, Pennsylvania, New York, and Massachusetts in place of the New York, Pennsylvania, Massachusetts combination. The results were essentially the same as shown in Table 6 and Figures 3 to 5. Data from Mississippi were left out of the analyses, because there was no obvious choice whether to combine them with Louisiana or with Alabama, both of which had sufficient isolates to be included on their own. Isolates from Tennessee could have been distributed among Georgia, Alabama, and Mississippi depending on the part of the state that they came from, but there were so few of them that they would have had little or no impact. Likewise, the number of isolates from Montana was so small that there would have been no value in including them with the North Dakota isolates.
Virulence complexity. Virulence frequencies on the 20 differential lines for which no significant changes occurred from 1990 to 2000 (Table 2) were calculated for each region, and the adjusted $\chi^{2}$ test for interaction was used to determine whether frequencies for virulence on each differential were homogeneous between pairs of regions (Table 7). Because of the large number of comparisons, a conservative test of significance at $P<0.01$ was used. By this test, virulence frequencies in the North and the South differed significantly on 14 of the 20 differentials. Virulence frequencies between the South and the central states did not differ $(P<0.01)$ on any of the differentials, but frequencies between the North and the central states differed significantly on four differentials,

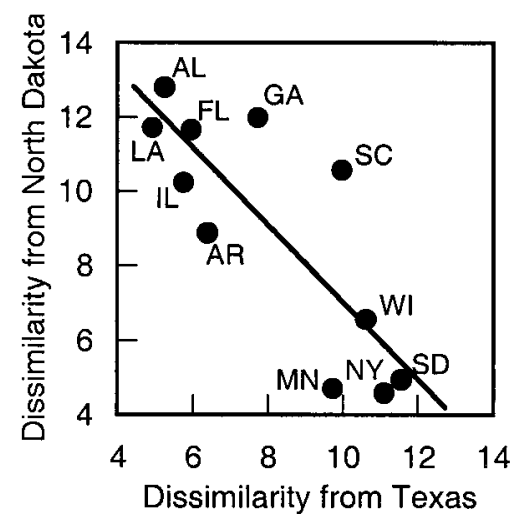

Fig. 3. Similarity of virulence frequencies in collections of Puccinia coronata f. sp. avenae from individual or pooled states compared to virulence frequencies in North Dakota collections versus Texas collections. Data points are labeled by state. AR represents pooled isolates from Arkansas, Oklahoma, Kansas, and $\mathrm{Ne}-$ braska; IL represents pooled collections from Illinois and Iowa; SC represents pooled collections from South Carolina, North Carolina, and Virginia; and NY represents pooled collections from New York, Pennsylvania, and Massachusetts. Isolates from California are excluded.
$P c-58, P c-59, P c-60$, and $P c-61$. Virulence frequencies on 10 of the 20 differentials differed significantly $(P<0.01)$ between California and the South. Three of the

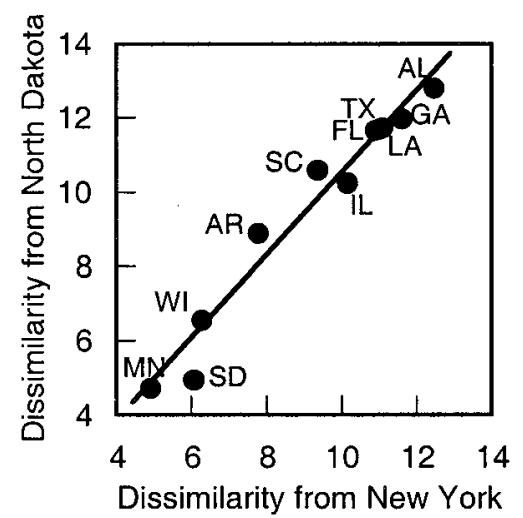

Fig. 4. Similarity of virulence frequencies in collections of Puccinia coronata f. sp. avenae from individual or pooled states compared to frequencies of virulence in North Dakota collections versus pooled collections from New York, Pennsylvania, and Massachusetts.

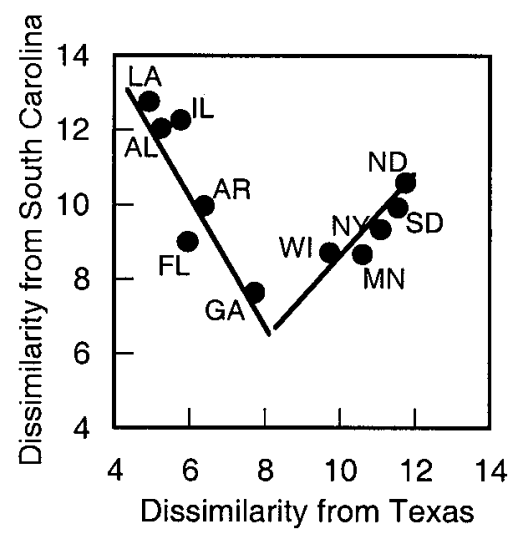

Fig. 5. Similarity of virulence frequencies in collections of Puccinia coronata f. sp. avenae from individual or pooled states compared to pooled South Carolina, North Carolina, Virginia collections versus Texas collections.

Table 6. Mean difference in virulence frequency ${ }^{\mathrm{a}}(\%)$ between collections of Puccinia coronata f. sp. avenae tested on 20 differential oat lines

\begin{tabular}{|c|c|c|c|c|c|c|c|c|c|c|c|c|c|}
\hline State & $\mathbf{T X}$ & LA & $\mathbf{A L}$ & FL & GA & $\mathbf{S C}^{\mathbf{b}}$ & $\mathbf{A} \mathbf{R}^{\mathbf{c}}$ & $\mathbf{I L}^{\mathbf{d}}$ & $\mathrm{NY}^{\mathrm{e}}$ & WI & MN & SD & ND \\
\hline TX & 0 & & & & & & & & & & & & \\
\hline LA & 4.91 & 0 & & & & & & & & & & & \\
\hline $\mathrm{AL}$ & $\underline{5.24}$ & $\underline{5.46}$ & 0 & & & & & & & & & & \\
\hline FL & 5.94 & 9.21 & 5.62 & 0 & & & & & & & & & \\
\hline GA & $\overline{7.72}$ & 11.06 & $\overline{9.44}$ & 4.94 & 0 & & & & & & & & \\
\hline $\mathrm{SC}^{\mathrm{b}}$ & 9.95 & 12.76 & 12.05 & $\overline{9.00}$ & 7.65 & 0 & & & & & & & \\
\hline $\mathrm{AR}^{\mathrm{c}}$ & 6.38 & 6.51 & 7.70 & 6.07 & 8.89 & 9.97 & 0 & & & & & & \\
\hline $\mathrm{IL}^{\mathrm{d}}$ & 5.75 & 6.16 & 8.21 & $1 \overline{0.39}$ & 11.62 & 12.27 & 7.16 & 0 & & & & & \\
\hline $\mathrm{NY}^{\mathrm{e}}$ & $1 \overline{1.07}$ & $1 \overline{1.01}$ & 12.44 & 10.88 & 11.58 & 9.34 & 7.78 & 10.14 & 0 & & & & \\
\hline WI & 10.59 & 10.70 & 12.36 & 11.29 & 11.28 & 8.67 & 8.49 & 7.40 & 6.26 & 0 & & & \\
\hline MN & 9.71 & 10.06 & 11.37 & 10.26 & 10.47 & 8.72 & 7.55 & 8.13 & $\overline{4.90}$ & 3.96 & 0 & & \\
\hline SD & 11.53 & 10.73 & 12.78 & 11.61 & 10.96 & 9.92 & 8.85 & 8.65 & 6.05 & 4.17 & 3.54 & 0 & \\
\hline ND & 11.73 & 11.72 & 12.81 & 11.67 & 11.99 & 10.59 & 8.89 & 10.25 & 4.59 & 6.57 & 4.72 & 4.95 & 0 \\
\hline $\mathrm{CA}^{\mathrm{f}}$ & 20.78 & 22.85 & 22.94 & 20.16 & 18.05 & 14.70 & 19.38 & 21.24 & $1 \overline{3.89}$ & $1 \overline{6.22}$ & $1 \overline{5.81}$ & $1 \overline{6.94}$ & 15.45 \\
\hline
\end{tabular}

a Mean differences of less than 7.0 are underlined to highlight regions of greatest similarity of virulence frequencies.

${ }^{\mathrm{b}}$ Includes pooled data from South Carolina, North Carolina, and Virginia.

${ }^{c}$ Includes pooled data from Arkansas, Oklahoma, Kansas, and Nebraska.

${ }^{\mathrm{d}}$ Includes pooled data from Illinois and Iowa.

e Includes pooled data from New York, Pennsylvania, and Massachusetts.

${ }^{\mathrm{f}}$ Includes one isolate from Arizona. 
differentials showed extreme differences; virulence on lines with $P c-45, P c-46$, and $P c-54$ occurred at much greater frequency among isolates from California than from the rest of the United States. Also, the virulence frequencies on lines with $P c-60$ and $P c-61$ were much lower in California than in the South.

Virulence complexity was calculated as the mean number of differential lines susceptible to each isolate from each state or pooled collection. Collections of isolates from the South (Texas, Louisiana, Alabama, Florida, Georgia, and South Carolina, North Carolina, Virginia) had greater virulence complexity than those from the North (North Dakota, South Dakota, Minnesota, Wisconsin, and New York, Pennsylvania, Massachusetts) (Fig. 6). The mean virulence complexity for southern states, 6.78, was significantly greater $(P=$ $\left.1.9 \times 10^{-5}\right)$ than that for northern states, 5.19. The mean virulence complexity for the central states (Arkansas, Oklahoma, Kansas, Nebraska, and Illinois, Iowa), 6.15 , was intermediate between that of the southern and northern states. Virulence complexity of the isolates from California was as great as that of the southern states (Fig. 6).

When all 28 differentials were considered, there was a significant increase in average virulence complexity among isolates from Texas from 1990 to 2000, but no significant increase among pooled isolates from Minnesota, North Dakota, and South Dakota (Fig. 7). In each of the first 4 years, isolates from Minnesota, North Dakota, and South Dakota had greater average virulence complexity than isolates from Texas, but in the following 7 years, the average virulence complexity of isolates from Texas was greater in every year.

\section{DISCUSSION}

All but one of the 28 crown rust resistance genes represented in the set of differential lines were derived from accessions of the wild oat $A$. sterilis collected in the Middle East, North Africa, or Portugal (3,5,7,20,26,28). Pc-14 came from the Brazilian cultivar Ascencao (A. sativa) (16). Virulence to all 28 differential lines occurred in the United States, although frequencies of virulence to specific resistance genes ranged from 1 or $2 \%$ for $P c-68$ to 79 to $88 \%$ for $P c-14$.

Relatively little information is available about the crown rust resistance genotypes of commonly grown oat cultivars, but at least 16 of the 28 genes in the differentials have been used in North America. Pc-48, $P c-62$, and $P c-68$ have been used in breeding lines in Manitoba, but cultivars with those genes were released too recently to have influenced the virulence frequencies reported in this study. $P c-58$ and $P c-59$ were used in the winter oat cultivars TAM O-301 and TAM O-312 in Texas in the 1970s and 1980s, and $P c-60$ and $P c-61$ were used in winter oat cultivars released by Coker Seed Co. in the mid-1970s. In addition, $P c-60$ and $P c-61$ are in the spring oat cultivars Hazel and Don, respectively, both of which were released in Illinois in 1985 and were grown as far north as Minnesota and as far west as Nebraska for several years $(1,4)$. Pc-58 apparently was also used in line D520, one of the nine components of the Iowa multiline cultivar Webster, because the source of its crown rust resistance was the same A. sterilis accession that provided the resistance in TAM O-301 (5). Frequencies of virulence to $P c-58, P c-59, P c-60$, or $P c-61$ did not increase significantly in either Texas or the northern Great Plains states during 1990 to 2000.

$P c-14, P c-36, P c-46, P c-51, P c-52, P c-$ 53, $P C-57, P C-58$, and $P C-71$ were used in Iowa multiline cultivars released in the 1980s (5). Pc-70 occurs in a line from the Iowa oat breeding program, but it may not have been included in any of the multiline

Table 7. Mean virulence frequencies (\%) in collections of Puccinia coronata f. sp. avenae by region ${ }^{\mathrm{a}}$ from 1990 to 2000

\begin{tabular}{lcccc}
\hline Line & South & Central & North & California \\
\hline$P c-14$ & 87 & 88 & 87 & 79 \\
$P c-35$ & $57 \mathrm{n}^{\mathrm{b}}$ & 57 & 41 & $30 \mathrm{~s}^{\mathrm{c}}$ \\
$P c-40$ & $86 \mathrm{n}$ & 84 & 72 & $56 \mathrm{~s}$ \\
$P c-45$ & $12 \mathrm{n}$ & 11 & 4 & $72 \mathrm{~s}$ \\
$P c-46$ & $29 \mathrm{n}$ & 27 & 34 & $70 \mathrm{~s}$ \\
$P c-48$ & 7 & 8 & 7 & $28 \mathrm{~s}$ \\
$P c-50$ & $24 \mathrm{n}$ & 16 & 10 & 21 \\
$P c-51$ & $71 \mathrm{n}$ & 66 & 51 & 50 \\
$P c-52$ & 5 & 1 & 6 & 7 \\
$P c-53$ & $4 \mathrm{n}$ & 3 & 1 & $72 \mathrm{~s}$ \\
$P c-54$ & $26 \mathrm{n}$ & 15 & 14 & 12 \\
$P c-58$ & $24 \mathrm{n}$ & 19 & $8 \mathrm{c}^{\mathrm{d}}$ & $37 \mathrm{~s}$ \\
$P c-59$ & $45 \mathrm{n}$ & 42 & $27 \mathrm{c}$ & $30 \mathrm{~s}$ \\
$P c-60$ & $77 \mathrm{n}$ & 73 & $54 \mathrm{c}$ & 5 \\
$P c-61$ & $71 \mathrm{n}$ & 57 & $41 \mathrm{c}$ & 16 \\
$P c-62$ & $2 \mathrm{n}$ & 5 & 5 & 53 \\
$P c-64$ & 7 & 12 & 9 & 7 \\
$P c-67$ & $52 \mathrm{n}$ & 33 & 38 & 7 \\
$P c-68$ & 2 & 1 & 1 & 6 \\
H548 & 4 & 4 & 6 & \\
\hline
\end{tabular}

a Mean frequencies of virulence were calculated for isolates collected within the southern (Texas, Louisiana, Alabama, Florida, Georgia, South Carolina, North Carolina, and Virginia), northern (North Dakota, South Dakota, Minnesota, Wisconsin, New York, Pennsylvania, and Massachusetts), and central (Arkansas, Oklahoma, Kansas, Nebraska, Illinois, and Iowa) regions. (See Figure 1 for numbers of isolates per state in each region.) Differential lines for which virulence frequencies changed significantly (linear regression, $P<0.05$ ) from 1990 to 2000 in either the South or the North were excluded from the comparisons to avoid year of collection bias among states.

${ }^{\mathrm{b}} \mathrm{n}$ indicates frequencies of virulence in the South that differ significantly $(P<0.01)$ from those in the North by interaction $\chi^{2}$ test for homogeneity.

${ }^{\mathrm{c}} \mathrm{s}$ indicates frequencies of virulence in California that differ significantly $(P<0.01)$ from those in the South by interaction $\chi^{2}$ test for homogeneity.

${ }^{d} \mathrm{c}$ indicates frequencies of virulence in the North that differ significantly $(P<0.01)$ from those in the central region by interaction $\chi^{2}$ test for homogeneity. None of the frequencies in the South were significantly different from those in the central region.

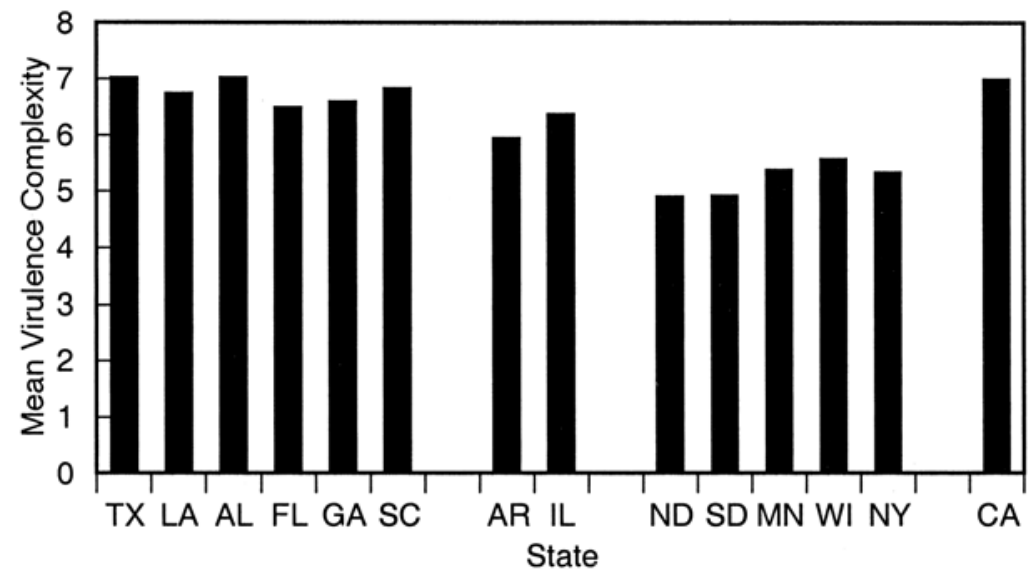

Fig. 6. Mean virulence complexity for collections of isolates of Puccinia coronata f. sp. avenae from states in the southern, central, northern, and western regions of the United States. Virulence complexities were calculated as the mean number of oat lines susceptible to each isolate from among the 20 differential lines for which no significant changes in virulence occurred from 1990 to 2000. 
cultivars that were released. Even those genes that were used in multiline cultivars could not have had a dominant role in crown rust resistance even in Iowa, because each multiline had 8 to 10 component lines, each with a different crown rust resistance gene, mixed in approximately equal proportions. By 1989, 'Multiline E', released in 1968, was still grown on approximately 15 to $20 \%$ of the oat acreage in Iowa, but 'Multiline M' had been discontinued because of grower dissatisfacreleased in 1984 (5) and contained the same nine $P c$ genes used in 'Multiline E' and 'Multiline M', continued to be grown into the 1990s. Frequencies of virulence to $P c-36, P c-57, P c-70$, and $P c-71$ increased significantly in Texas and in the northern Great Plains states of Minnesota, North Dakota, and South Dakota from 1990 to 2000. It seems unlikely that these increases could be due primarily to the limited use of these genes in the Iowa multilines during the 1980 s and early 1990s. On the other hand, all of the component lines of 'Webster' were also released as parental germ plasm lines (6), so some of the $P c$ genes from the Iowa multilines may have entered oat breeding programs elsewhere in the Midwest.

$P c-38$ and $P c-39$ were used extensively in Manitoba, North Dakota, and Minnesota during the 1980s and early 1990s (1). By 1990, the frequencies of virulence to $P c-38$ and $P c$ - 39 were already high in the northern Great Plains states, and these frequencies did not increase significantly between 1990 and 2000. Virulence to $P c-38, P c-39$, and $P c-63$, however, did increase signifition. The multiline Webster, which was in Iowa and to some extent in Minnesota

cantly in frequency in Texas. It seems likely that these increases were at least partly due to gene flow from the northern Plains to Texas after selection by resistant cultivars in the northern Great Plains produced the high virulence frequencies there. Although $P c-63$ has not been used to a significant extent in commercial oat production, the increase in virulence to $P c-63$ closely parallels that of virulence to $P c-38$. All isolates virulent to $P c-63$ have been found to be virulent also to $P c-38$, although some isolates virulent to $P c-38$ lack virulence to $P c-63$ (1).

Collections of isolates of $P$. coronata $\mathrm{f}$. sp. avenae from 14 states or groups of states were compared for frequency of virulence on the 20 differential lines for which there was no significant change in virulence from 1990 to 2000 to determine regional variation in populations of $P$. coronata f. sp. avenae. It is not known whether these virulence genes represent neutral markers or whether the apparent stability in their frequencies represents a form of balancing selection around an equilibrium frequency. For these 20 virulences, the collections of $P$. coronata $\mathrm{f}$. $\mathrm{sp}$. avenae from California and Arizona clearly differed from those from other parts of the United States. In addition, the collections from northern states clustered together as different from the collections from the South. In the North, there was no apparent correlation between similarity indexes based on virulence frequency and geographical distance between the states. In the South, however, there was a negative correlation between similarity to collections from Texas versus similarity to the pooled collections from South Carolina,

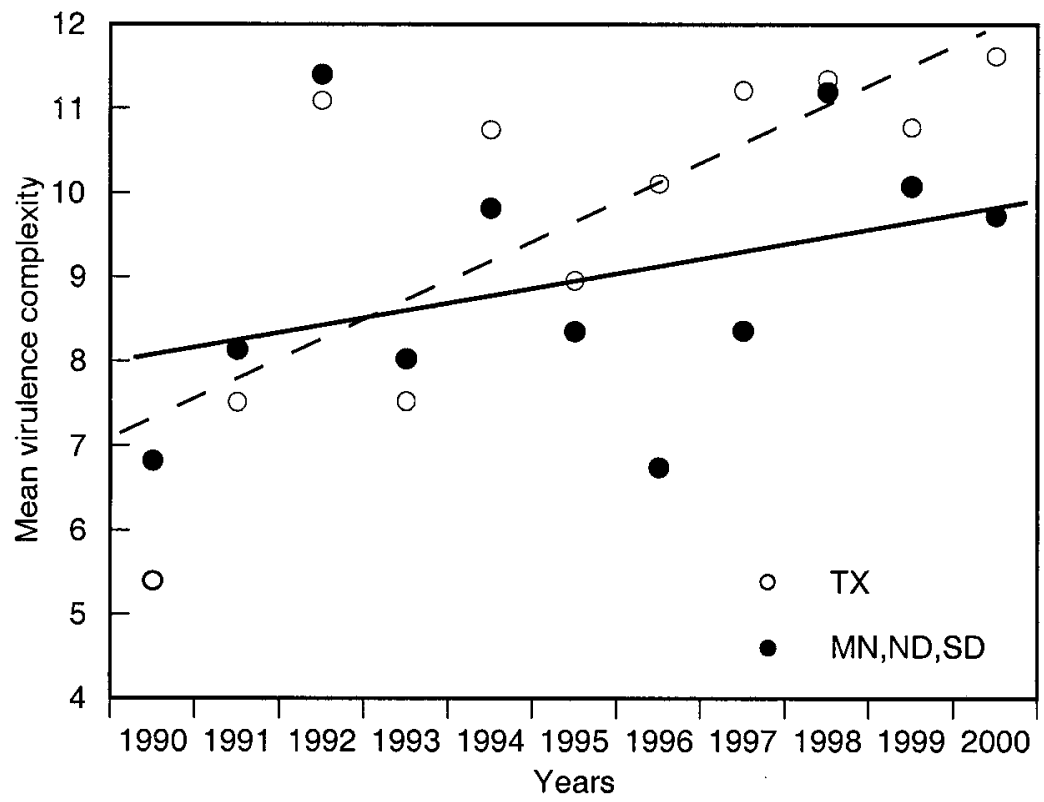

Fig. 7. Mean virulence complexity based on all 28 oat differentials for collections of isolates of Puccinia coronata f. sp. avenae from Texas (open circles, dashed line) and pooled isolates from Minnesota, North Dakota, and South Dakota (closed circles, solid line) over the years 1990 to 2000. The slope of the regression for Texas isolates is significantly greater than $0.0(P<0.01)$; the slope for the Minnesota, North Dakota, South Dakota isolates is not significantly different from $0.0(P>0.05)$.
North Carolina, and Virginia. This indicates a gradient of genetic difference from Texas to the Atlantic Coast states in the South.

Annual movement of cereal rust urediniospores from the southern Great Plains states northward to the northern Great Plains and the Ohio Valley is well documented $(11,19)$. North to south movement of wheat rust in late summer and fall, although of smaller magnitude than south to north movement in spring and early summer, was considered an important source of inoculum contributing to initial infection of winter wheat in the South during the early 1900s. However, Roelfs (18) argued that north to south movement of wheat stem rust was no longer significant in the last half of the twentieth century. One reason for this conclusion was that new races of wheat stem rust often appeared for several years in the South before they were detected in the North. Roelfs (18) concluded that the nearly complete resistance of spring wheat cultivars to stem rust in the northern Great Plains had largely eliminated the availability of fall inoculum for north to south movement of urediniospores in late summer. This argument does not apply to oat crown rust, for which resistance breeding has not achieved a high level of success in either the North or the South (13). Thus, it is likely that north to south movement of $P$. coronata $\mathrm{f}$. sp. avenae urediniospores continues to occur in the late summer and fall in the Great Plains.

Evidence for genetically distinct populations of $P$. coronata $\mathrm{f}$. sp. avenae in the North and the South is important. It shows that in spite of a known mechanism for gene flow, the populations of $P$. coronata f. sp. avenae in the North and South remain distinct. Apparently there are unknown mechanisms that account for differences in virulence frequencies between these regions even when there is no apparent selection by resistant oat cultivars affecting the 20 virulences included in these analyses. Virulence that is present in cereal rust populations in the absence of corresponding resistance in the host population is termed unnecessary virulence and is commonly regarded as evidence against a fitness cost for the virulence. However, the possible pleiotropic effects of these genes on fitness cannot be dismissed entirely in view of the maintenance of different virulence frequencies in northern and southern regions of the United States in spite of opportunities for gene flow between them.

The direction of gene flow between rust populations is obviously affected by the direction of prevailing winds during rust epidemics, but it also will be affected by the relative sizes of potential donor populations for migrants. The northern states included in this survey account for $68 \%$ of the total harvested oat area in the 1990s, while the southern states account for only 
9\%. Thus, the North could potentially provide a much larger pool of migrants to the South compared with the pool of migrants from south to north. It is interesting, therefore, that collections of $P$. coronata $\mathrm{f}$. $\mathrm{sp}$. avenae from the central region represented by Arkansas, Oklahoma, Kansas, Nebraska, and Illinois, Iowa showed greater similarity in virulence frequencies to the collections from the South than to those from the North. Apparently, migration from south to north is greater than migration from north to south for $P$. coronata $\mathrm{f}$. sp. avenae in the United States. Unfortunately, the central states were underrepresented in this comparison. Although the central states had $22 \%$ of the harvested oat acreage in the $1990 \mathrm{~s}$, only $4 \%$ of the isolates of $P$. coronata $\mathrm{f}$. sp. avenae were obtained from the central states.

With regard to the 20 genes for which virulence frequencies did not change from 1990 to 2000, the average virulence complexity for isolates of $P$. coronata $\mathrm{f}$. sp. avenae from southern states was significantly greater than the virulence complexity of isolates from the North. Virulence complexity of isolates from central states was intermediate between that of the southern and northern isolates. Surprisingly, the virulence complexity in California, which has a great abundance of wild $A$. fatua, was as great as that for the southern states, where only a few isolates of $P$. coronata f. sp. avenae from A. fatua were found in Texas. Presumably, the population of $P$. coronata $\mathrm{f}$. sp. avenae in California has little, if any, exposure to the $P c$ genes from A. sterilis that were used in the differentials in this study. A. sterilis is much less common in California than A. fatua; its known distribution is limited to the San Francisco Bay area, whereas A. fatua is found throughout nearly all of California (8).

The greater virulence complexity in collections of $P$. coronata f. sp. avenae from the southern than from the northern United States is similar to the pattern reported in Europe. Data from Sebesta and Harder (21) and Sebesta et al. (22) show that collections from Italy, Portugal, Spain, Yugoslavia, and Israel had greater virulence complexity than collections from central and northern Europe. Isolates from Switzerland, Denmark, and Germany had the least virulence complexity among European collections in 1977 to 1980 (21), and collections from Belgium, Estonia, Great Britain, and Sweden had the least in 1990 to 1994 (22), although the numbers of isolates from 1990 to 1994 were very low. Also, the pattern of high frequencies of virulence to $P c-45, P c-46$, and $P c-54$ in collections from California was similar to the high frequencies of virulence to these three resistance genes in Italy, Portugal, and Yugoslavia relative to other countries of Europe or other areas of the United States (21).
When all 28 differentials were considered, the average virulence complexity increased significantly from 1990 to 2000 among isolates from Texas but not among pooled isolates from Minnesota, North Dakota, and South Dakota. This can be attributed to the increased frequency of virulence to $P c$-38 and $P c$-39 from 1990 to 2000 in Texas but not in the northern Great Plains. Thus, any comparison of virulence complexity between pathogen populations is conditional upon the array of virulences tested and the time frame for the comparison. Therefore, the comparisons of regional virulence complexity based on the 20 differential lines reported in this study should not be regarded as indicative of overall virulence complexity. Instead, they may represent different levels of complexity relative to a set of known virulences that have remained stable over many years. Of course, widespread use of several new genes for race-specific resistance within any of the regions represented in this study might be expected to select for an increase in virulence complexity within that region.

The greater mean virulence complexity in collections of $P$. coronata $\mathrm{f}$. sp. avenae isolates from Texas than from states in the northern Great Plains is in contrast to the general rule (12) that virulence complexity in pathogen populations increases in the direction of predominant dispersal on prevailing winds in continental movement of epidemics. That effect, however, is attributed to stepwise selection of new virulence genes as the pathogen encounters new resistant host cultivars during successive long-distance dispersal events. Most, if not all, of the 20 stable virulences represented in the calculations of virulence complexity in regions of the United States reported in this study could be regarded as unnecessary virulence not selected by resistant host cultivars in either the South or the North. Thus, it is apparent that populations of $P$. coronata f. sp. avenae in the United States support a large amount of unnecessary virulence and that the amount differs in different geographical regions.

The fact that frequencies of virulence corresponding to 20 of the 28 resistance genes in the set of differential lines did not change significantly over the 11-year period of 1990 to 2000 does not necessarily mean that those virulence genes are selectively neutral in the absence of corresponding resistance genes in the host population. On the contrary, there may be unknown forces of balancing selection that tend to prevent fixation of either the alleles for virulence or those for avirulence under most conditions. Another possibility is that genotypes heterozygous at virulence/ avirulence loci may have superior fitness. Genetic recombination during the sexual cycle, which occurs at least in the North, would reestablish a proportion of virulent (or avirulent) homozygotes each year. Future studies that are under way and may shed light on this question include analyses of virulence frequencies among isolates of $P$. coronata f. sp. avenae collected from wild $A$. sterilis in Israel, where many of the $P c$ genes used in this study are known to occur naturally in the host population, and from cultivated A. sativa in Brazil, where crown rust susceptible Rhamnus spp. and the sexual stage of $P$. coronata $\mathrm{f}$. sp. avenae do not occur.

It would be useful also to compare polymorphisms for DNA markers in collections of $P$. coronata f. sp. avenae from different regions of the United States to see if the patterns found with DNA markers correspond to those seen with virulence genes that showed stable frequencies. For example, it is quite possible that randomly amplified polymorphic DNA (RAPD) or amplified fragment length polymorphism (AFLP) markers for collections of P. coronata f. sp. avenae from the northern Great Plains and the Northeast of the United States may differ as they do for collections of $P$. triticina from the Prairie Provinces and eastern Canada $(9,10)$, even if frequencies of virulences in $P$. coronata f. sp. avenae do not. If this were the case, it would be evidence that the seemingly unselected virulences in $P$. coronata f. sp. avenae may not be selectively neutral in the absence of their corresponding resistance genes in the host populations.

The large number of stable virulence polymorphisms present in populations of $P$. coronata $\mathrm{f}$. sp. avenae in the absence of obvious selection pressure from corresponding host resistance genes could be explained by an unknown form of stabilizing selection that is subject to climatic influences. If there were no balancing selection, the south to north movement of urediniospores each summer would be expected to result in the population of $P$. coronata f. sp. avenae in Minnesota, North Dakota, and South Dakota being more similar in virulence frequencies to the population in Texas rather than to that in the northeastern states.

\section{ACKNOWLEDGMENTS}

The excellent technical assistance of G. E Ochocki and V. A. Brewster in establishing and testing single-uredinial isolates of $P$. coronata $\mathrm{f}$. sp. avenae is gratefully acknowledged, as is the generous support of the many cooperators who submitted collections of oat crown rust from throughout the United States. The helpful suggestions from J. A. Kolmer, J. V. Groth, and E. Kosman, who reviewed this work, are also much appreciated.

\section{LITERATURE CITED}

1. Chong, J., and Kolmer, J. A. 1993. Virulence dynamics and phenotypic diversity of Puccinia coronata f. sp. avenae in Canada from 1974 to 1990 . Can. J. Bot. 71:248-255.

2. Chong, J., Leonard, K. J., and Salmeron, J. J. 2000. A North American system of nomenclature for Puccinia coronata f. sp. avenae. Plant Dis. 84:580-585.

3. Fleischmann, G., and Baker, R. J. 1971. Oat crown rust race differentiation: Replacement of the standard differential varieties with a 
new set of single resistance gene lines derived from Avena sterilis. Can. J. Bot. 49:14331437.

4. Frey, K. J. 1991. Genetic resources of oats. Pages 15-24 in: Use of Plant Introductions in Cultivar Development, Part 1. H. L. Shands and L. E. Wiesner, eds. Crop Sci. Soc. Am. Spec. Publ. No. 17.

5. Frey, K. J., Simons, M. D., Michel, L. J., Murphy, J. P., and Browning, J. A. 1988. Registration of 'Webster' oat. Crop Sci. 28:374-375.

6. Frey, K. J., Simons, M. D., Michel, L. J. Murphy, J. P., and Browning, J. A. 1988. Registration of Webster oat isolines as parental lines. Crop Sci. 28:386-387.

7. Harder, D. E., McKenzie, R. I. H., and Martens, J. W. 1980. Inheritance of crown rust resistance in three accessions of Avena sterilis. Can. J. Genet. Cytol. 22:27-33.

8. Hickman, J. C. 1993. The Jepson Manual: Higher Plants of California. University of California, Berkeley.

9. Kolmer, J. A. 2001. Molecular polymorphism and virulence phenotypes of the wheat leaf rust fungus Puccinia triticina in Canada. Can. J. Bot. 79:917-926.

10. Kolmer, J. A., Liu, J. Q., and Sies, M. 1995. Virulence and molecular polymorphism in Puccinia recondita f. sp. tritici in Canada. Phytopathology 85:276-285.

11. Leonard, K. J., Roelfs, A. P., and Long, D. L. 1992. Diversity of virulence within and among populations of Puccinia recondita $\mathrm{f}$. sp. tritici in different areas of the United States. Plant Dis. 76:500-504.

12. Limpert, E., Godet, F. G., and Müller, K.
1999. Dispersal of cereal mildews across Europe. Agric. For. Meteorol. 97:293-308

13. Long, D. L., and Hughes, M. E. 2003. Small Grain Losses Due to Rust. U.S. Dep. Agric. Agric. Res. Serv., Cereal Disease Lab. On-line publication CDL-EP\#007. Updated annually.

14. Long, D. L., Leonard, K. J., and Roberts, J. J. 1998. Virulence and diversity of wheat leaf rust in the United States in 1993 to 1995. Plant Dis. 82:1391-1400.

15. McDonald, B. A. 1997. The population genetics of fungi: Tools and techniques. Phytopathology 87:448-453.

16. Michel, L. J., and Simons, M. D. 1985. Registration of oat germplasms IA H676, IA H677, and IA H681 resistant to the oat crown rust fungus. Crop Sci. 25:716-717.

17. Murphy, H. C. 1935. Physiologic specialization in Puccinia coronata avenae. U.S. Dep. Agric. Tech. Bull. 433.

18. Roelfs, A. P. 1985. Monitoring stem rust epidemics in the Great Plains. Pages 527-532 in: The Movement and Dispersal of Agriculturally Important Biotic Agents. D. R. McKenzie, C. S. Barfield, G. C. Kennedy, R. D. Berger, and D. J. Taranto, eds. Claitors, Baton Rouge, LA.

19. Roelfs, A. P. 1989. Epidemiology of the cereal rusts in North America. Can. J. Plant Pathol. 11:86-90.

20. Roelfs, A. P., Hughes, M. E., and Long, D. L. 2003. Catalog of Rust Resistance Genes in Small Grains. U.S. Dep. Agric. Agric. Res. Serv., Cereal Disease Lab. On-line publication CDL-EP\#005. Updated annually.

21. Sebesta, J., and Harder, D. E. 1983. Occur- rence and distribution of virulence in $P u c$ cinia coronata var. avenae in Europe, 19771980. Plant Dis. 67:56-59.

22. Sebesta, J., Zwatz, B., Harder, D. E., Corazza, L., and Stojanovic, S. 1997. Incidence of crown rust and virulence of Puccinia coronata on oat and the effectiveness of $P C$-genes for resistance in Europe during 1990-1994. Arch. Phytopathol. Pflanzenschutz 30:507518.

23. Sherf, A. F. 1954. The 1953 crown and stem rust epidemics of oats in Iowa. Proc. Iowa Acad. Sci. 61:161-169.

24. Simons, M. D. 1955. An examination of the present status and proposed modifications of the annual crown rust race survey in the United States. Plant Dis. Rep. 39:956-959.

25. Simons, M. D. 1985. Crown rust. Pages 131 172 in: The Cereal Rusts: Vol. II. Diseases, Distribution, Epidemiology, and Control. A. P. Roelfs and W. R. Bushnell, eds. Academic Press, Orlando, FL.

26. Simons, M. D., Martens, J. W., McKenzie, R I. H., Nishiyama, I., Sadanaga, K., Sebesta, J. and Thomas, H. 1978. Oats: A standardized system of nomenclature for genes and chromosomes and catalog of genes governing characters. USDA Agric. Handb. no. 509.

27. Steel, R. G. D., and Torrie, J. H. 1960. Principles and Procedures of Statistics. McGrawHill, New York.

28. Wong, L. S. L., McKenzie, R. I. H., Harder, D. E., and Martens, J. W. 1983. The inheritance of resistance to Puccinia coronata and of floret characters in Avena sterilis. Can. J. Genet. Cytol. 25:329-335. 